University of Arkansas, Fayetteville

ScholarWorks@UARK

Education Reform Faculty and Graduate

Students Publications

Education Reform

9-5-2017

\title{
Does Regulation Induce Homogenization? An Analysis of Three Voucher Programs in the United States
}

\author{
Corey A. DeAngelis \\ University of Arkansas, Fayetteville, cadeange@uark.edu \\ Lindsey Burke \\ George Mason University
}

Follow this and additional works at: https://scholarworks.uark.edu/edrepub

Part of the Educational Assessment, Evaluation, and Research Commons, Educational Leadership Commons, and the Other Educational Administration and Supervision Commons

\section{Citation}

DeAngelis, C. A., \& Burke, L. (2017). Does Regulation Induce Homogenization? An Analysis of Three Voucher Programs in the United States. Education Reform Faculty and Graduate Students Publications. Retrieved from https://scholarworks.uark.edu/edrepub/6

This Article is brought to you for free and open access by the Education Reform at ScholarWorks@UARK. It has been accepted for inclusion in Education Reform Faculty and Graduate Students Publications by an authorized administrator of ScholarWorks@UARK. For more information, please contact scholar@uark.edu. 


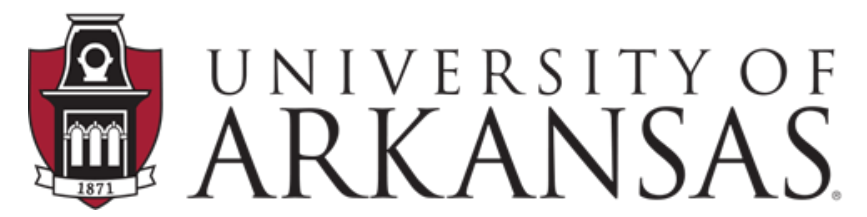

College of Education \& Health Professions Education Reform

\section{WORKING PAPER SERIES}

\section{Does Regulation Induce Homogenization? An Analysis of Three Voucher Programs in the United States}

Corey A. DeAngelis

Lindsey M. Burke

September 5, 2017

EDRE Working Paper 2017-14

The University of Arkansas, Department of Education Reform (EDRE) working paper series is intended to widely disseminate and make easily accessible the results of EDRE faculty and students' latest findings. The Working Papers in this series have not undergone peer review or been edited by the University of Arkansas. The working papers are widely available, to encourage discussion and input from the research community before publication in a formal, peer reviewed journal. Unless otherwise indicated, working papers can be cited without permission of the author so long as the source is clearly referred to as an EDRE working paper. 
Does Regulation Induce Homogenization? An Analysis of Three Voucher Programs in the United States

\author{
Corey A. DeAngelis \\ Department of Education Reform, \\ University of Arkansas \\ and \\ Policy Analyst, Center for Educational Freedom \\ Cato Institute \\ CDeAngelis@cato.org \\ Lindsey Burke \\ George Mason University \\ and \\ Director, Education Policy Studies, \\ The Heritage Foundation \\ Lindsey.Burke@heritage.org
}

September 5, 2017

\title{
Acknowledgements
}

The content of the report is solely the responsibility of the authors and does not necessarily represent the views of the Cato Institute, the University of Arkansas, George Mason University, or The Heritage Foundation. Corresponding author is Corey A. DeAngelis, CDeAngelis@ cato.org. 


\begin{abstract}
We employ school and year fixed-effects regression to determine the effect of voucher programs on the supply of private schools. In particular, we examine individual private schools in Washington, D.C., Indiana, and Louisiana as they transition into voucher program environments. We leverage the Private School Universe Survey to examine how schools selfidentify before and after switching into voucher environments. We find that upon switching into school voucher programs, private schools in more heavily regulated programs are more likely to identify as less specialized than they were prior to entering the program, and that those schools in more lightly regulated environments continue to highlight their specialized approach to education. These findings are examined within an institutional theory framework to understand the potential homogenizing effect of regulations on the diversity of the private school market. Keywords: private school; school choice; schooling supply; school vouchers; organizational theory; institutional theory; isomorphism; homogenization
\end{abstract}




\section{Introduction}

With the recent confirmation of Betsy DeVos as U.S. Education Secretary, and with growing state adoption of voucher and other educational choice models, private school choice has become an important topic. Since private school choice options are being proposed in numerous states across the country, it is especially important to examine the impacts that program design has on students and the private schools that participate.

All but two of the twenty experimental evaluations of private school choice programs across the globe have found null to positive impacts on student achievement (Shakeel, Anderson, \& Wolf, 2016). One of these exceptions was an evaluation of the Louisiana Scholarship Program (LSP) (Abdulkadiroglu, Pathak, \& Walters, 2015), while the other is the most recent evaluation of the D.C. Opportunity Scholarship Program (OSP) (Dynarski et al., 2017). One theory for why the LSP produced large negative results is that the relatively high regulatory costs associated with program involvement disincentivized high quality schools from participating at all (Sude, DeAngelis, \& Wolf, 2017). Likewise, the regulatory costs associated with program participation may lead to homogenization of the supply of schooling. A homogenous supply of schools could produce negative academic results through the failure to match interests of students and educators.

As more private schools begin participating in a growing school voucher movement, the regulatory environment in which these school choice programs operate could reify existing norms about schooling while homogenizing a budding alternative education sector. If homogenization of the private school market occurs, it could do so in a way that limits innovation and, ultimately, the range of options available to families. We consider the impact of voucher participation on private schools in three locations through the lens of institutional 
theory, adding to our understanding of choice program design in ways largely unexplored within education policy.

\section{Literature Review}

\section{Impacts of Private School Choice}

Scholars have conducted numerous evaluations of the impact of school choice on academic achievement, academic attainment, resulting competitive pressure on surrounding public schools, and the impact on parental satisfaction. Although there are other areas with considerable research on the impact of school choice, pertaining, for example, to the effects of competitive pressure on public schools (Egalite, 2013; Hoxby, 2001; Carnoy et al., 2007), parent perceptions of school safety (Wolf et al., 2013), civic values (Howell \& Peterson, 2006; Fleming, Mitchell, \& McNally, 2014; \& Mills et al., 2016), fiscal impacts (Costrell, 2010; Scafidi, 2012), criminal activity (DeAngelis \& Wolf, 2016), and integration (Greene \& Winters, 2005; Greene, Mills, \& Buck, 2010; Egalite, Mills, \& Wolf, 2017), this brief review of the literature is confined to studies employing random assignment techniques, limiting the overview to the impact of school choice on academic achievement and attainment.

Building off of Forster's (2016) and Shakeel, Anderson, and Wolf's (2016) reviews of school choice evaluations, we find 19 total studies using random assignment methods; 16 of which analyze the impact of school choice on academic achievement, and three of which examine academic attainment impacts.

\section{Student Achievement}

To date, researchers have conducted 16 evaluations of the impact of school choice on participants' academic achievement using random assignment methods in the United States. Of those 16 evaluations, 10 found statistically significant positive gains on student achievement for 
some or all students (Rouse, 1998; Greene, Peterson, \& Du, 1999; Greene, 2000; Howell, Wolf, Campbell, \& Peterson, 2002 (contains three studies); Barnard et al., 2003; Cowen, 2008; Jin, Barnard, \& Rubin, 2010; Bitler et al., 2015), four found no impact (Krueger \& Zhu, 2004; Bettinger \& Slonim, 2006; Wolf et al., 2013; Mills \& Wolf, 2017), and two found negative impacts on academic achievement as a result of voucher use (Abdulkadiroglu, Pathak, \& Walters, 2015; Dynarski et al., 2017).

Authors from the experimental LSP studies suggest that one possible explanation for negative effects on academic achievement, unique among RCT evaluations of school choice programs, could be due to the low quality of private schools participating in the program. Just one-third of private schools in Louisiana chose to participate in the voucher program, and evidence suggests those that did may have been experiencing declining enrollments - a lagging indicator of school quality - prior to enrolling in the LSP (Abdulkadiroglu, Pathak, \& Walters, 2015). Further, researchers have found that the lower quality private schools, as measured by tuition and enrollment levels, were more likely to participate in the LSP (Sude, DeAngelis, \& Wolf, 2017).

\section{Student Attainment}

Three evaluations employing random assignment methods have examined the impact of school choice on students' academic attainment. All three found statistically significant improvements in attainment levels for school choice participants (Wolf et. al, 2013; Chingos \& Peterson, 2013; Chingos \& Peterson, 2015). Of note among the random assignment evaluations of the impact of school choice on academic attainment is the evaluation of the Washington, D.C. OSP. This evaluation of the impact of the D.C. OSP on student academic outcomes found that students who used a voucher to attend a private school of choice graduated at a rate 21- 
percentage points higher than the control group of students who applied for, but were not awarded a scholarship (Wolf et. al, 2013).

\section{Organizational Theory as a Framework}

Although the impact of school choice options such as vouchers has been studied at length, less consideration has been given to the impact the design of these programs can have on participating private schools' operations and character. The body of literature undergirding organization theory, which examines the structure and functions of organizations (Scott, 1987), provides a useful framework for more fully understanding the impact of voucher program participation on private schools. One subset of organization theory, known as institutional theory, examines the processes organizations undertake in order to establish legitimacy in a given environment, and surveys the root causes that lead organizations to reproduce the characteristics of other organizations over time. Institutional theory holds that organizations adopt certain structures over time, "in order to gain legitimacy" (Westwood \& Clegg, 2003, pg. 279). Working under the same relative set of conditions, entities that are isomorphic will begin to take on the characteristics of other entities (Hawley, 1968), while new entrants into the market will "seek to overcome the liability of newness by imitating established practices within the field" (DiMaggio \& Powell, 1983,pg. 156).

This institutional isomorphism - what DiMaggio and Powell (1983) referred to as the "inexorable push toward homogenization" and what Dacin (1997) argued is the process of "fit" complicates and shades what observers may have thought they knew about the impact of school voucher programs on the private education market.

\section{Complicating the Narrative: Institutional Isomorphism}


When considered in the context of K-12 education, institutional theory suggests that schools may simply copy other schools to conform to existing rules to generate social legitimacy (Oplatka, 2004). The literature of institutional theory suggests that it is possible, even within a private school choice market, that schools' structure will be constrained by the unwritten rules of what society considers schooling to be (Meyer, Scott, \& Deal, 1992), and that schools will incorporate "rationalized myths," adopting the vocabularies and organizational language of schools that preceded them (Meyer \& Rowan, 1978). It is also the case that schools could simply copy the existing beliefs of the environment in which they operate - the state, city, charter management organization, or private school network - out of fear that not doing so will create the perception that they are failing schools (Oplatka, 2004). At the same time, isomorphism results from more than just the influence of organizations on other organizations (Dacin, 1997). Parents, for example, have been identified as "inherently conservative consumers" and their need for consumer information about schools leads to "standardized criteria for evaluation" (Lubienski, 2003, pg. 420). These pressures compete with notion that through school choice, practices will differ across schools.

DiMaggio and Powell (1983) identified three types of isomorphic pressures: 1) coercive isomorphism, which includes formal and informal pressures to conform to existing systems, 2) mimetic isomorphism, which includes intentionally copying existing institutions in order to gain legitimacy, and 3) normative isomorphism, which includes unintentionally adopting the practices and values of other institutions and organizations. Although private schools, like any other education option, are susceptible to mimetic and normative isomorphic pressures, the types of regulations that govern private school voucher programs can determine whether coercive isomorphism occurs, limiting the diversity of private school type within a school choice 
program. As Astley and Van de Ven (1983) opined, "The player remains free, but if he wants to win he must adopt a strategy in reasonable conformance with the rules, since a complete abandonment of the game cannot serve his interests" (pg. 252). If homogenization does occur, it will limit one of the central tenants of school choice - the idea that practices will differ across schools, and as such, that schools will respond to parent and community preferences in a way that meets family needs and local demands (Berends et al., 2010).

\section{Theory}

Many voucher program proponents theorize that the additional financial incentives provided will entice market entry and specialized institutions. While this may appear intuitive in a setting where financial incentives are created spontaneously through dispersed customer-driven demand, the relationship is not so clear when the funding is provided from a centralized body. Since centralized direction is, by definition, comprehensively uniform, we should not expect that schooling providers will be more specialized. Moreover, since schooling regulation intends to limit the types of choices available to families, we should expect less heterogeneity in the supply of private schools.

Whenever an individual or institution receives funding from a provider, the provider is able to exercise some form of control over the receiving establishment. After all, the provider sends money to specific institutions if, and only if, they perceive to experience benefits from the transaction that exceed the costs. Oftentimes, the realized benefit is in the form of donor autonomy over the receiving organization. In order to ensure that the investment will be worthwhile, providers have the incentive to attach conditions to the transaction.

In the case of voucher programs, the provider of public funding is the taxpayers and the potential receiving institutions are private schools. Not surprisingly, in order to receive public 
funding for schooling operation, private schools must adhere to certain regulations determined through democratic institutions. Scholars theorize that if individuals choose goods and services based on rational self-interest, their choices may inadvertently harm society as a whole (Pigou, 1920). In other words, voluntary transactions between producers and consumers could affect involuntary third parties. Since positive and negative externalities may result from an unrestricted market, some economists argue that government regulation is necessary to protect society overall (Bator, 1958). For example, economists argue that a tax ought to be placed on companies that produce pollution, which harms the environment and the health of citizens that did not voluntarily enter the transaction. However, even the founder of the Pigovian tax, Arthur Pigou, cautioned that attempts to remedy market failures could result in even larger government failures (Pigou, 1920; Tullock, Brady, \& Seldon, 2002).

Some of the voucher program regulations, such as financial reporting and auditing, may not impose large costs on participating private schools. Others, however, may inadvertently change the overall mission, strategy, and composition of private schools. Costly conditions tied to funding include standardized testing requirements, open-admissions processes, teacher certification requirements, and the prohibition of parental copayment.

Private schools have a strong financial incentive to participate in voucher programs, especially since they are directly competing with a product that is free at the point of delivery: traditional public schools and public charter schools. Out of rational self-interest, schools choose to participate in programs; however, these choices may lead to private schools that look very much like traditional public schools if program regulations are decided by the same process that determines the operation of residentially assigned public schools. In that case, the conditions will reflect the traditional setting. 
The more costly and extensive the regulatory environment, the more likely it is that private institutions will behave like public schools. As a result, we expect that more highly regulated voucher program environments will increase homogenization of the supply of schools, with those that face the largest regulatory environments being the most likely to become isomorphic to their public school counterparts.

\section{The Programs}

\section{Indiana Choice Scholarship Program}

In 2011, Indiana launched its Choice Scholarship Program (CSP), which provides vouchers to eligible children to attend a private school of choice. More than 34,600 students currently participate in the CSP, which is open to children from families earning up to 150 of the federal poverty line ( $\$ 67,433$ for a family of four during the $2016-17$ academic year) or up to 200 percent of poverty for children with special needs (EdChoice, 2017). The regulations governing the CSP are considerable: the state is permitted to review private school curricula, instruction, classroom materials, and private schools must administer the state test. State testing outcomes and graduation rates of participating private schools are also used to assign an A-F letter grade, and schools receiving a D or $\mathrm{F}$ grade for two consecutive years lose program participation eligibility (EdChoice, 2017). Schools must also have sound accounting practices in place. Although these regulations are substantial, many private schools already adhered to some of them as a condition of participation in the Indiana High School Athletics Association (Cavazos, 2016).

\section{D.C. Opportunity Scholarship Program}

In 2004, Congress established the first federal K-12 school choice program, in the form of the D.C. OSP. More than 1,100 eligible children currently use an OSP voucher to attend a 
private school of choice in the District. To be eligible, children must come from families earning less than $\$ 44,955$ annually for a family of four (EdChoice, 2017). The D.C. OSP is relatively lightly regulated. Private school students using a voucher must take a nationally norm-referenced test, but the private school they attend is not required to administer the exam. Private schools must also allow site visits by the program administrator, and must have sound accounting systems in place.

\section{Louisiana Scholarship Program}

The Louisiana Scholarship Program was established as a statewide voucher program in 2012. It had previously be confined to New Orleans, operating within Orleans Parish since 2008. Some 7,100 students currently participate in the LSP, which is open to children from families earning less than $\$ 60,750$ annually, and who have also attended an underperforming school (rated C, D, F, or T) during the previous school year, are entering kindergarteners, or were enrolled in a public school in the Recovery School District (RSD).

The LSP is highly regulated. Participating private schools must use open enrollment, students on a scholarship must take the uniform state test, and schools must maintain a curriculum deemed on par with public schools (EdChoice, 2017). Participating private schools must employ a testing coordinator who must attend Board of Elementary and Secondary Education (BESE) testing workshops and any additional training required to administer the tests (Bulletin 133, 2014). The Louisiana Department of Education also monitors overall testing implementation and conducts school visits during testing periods (Bulletin 133, 2014). Schools with more than 10 scholarship students in each grade or more than 40 students overall are assigned a Scholarship Cohort Index (SCI) score. Schools that receive an SCI below 50 in year two an onward, or have less than a 25 percent proficiency rate on state assessments, are barred 
from enrolling new scholarship students during the subsequent year (Annual Report, 2013-2014).

For private schools that do provide special education services, they must provide information about what services will be offered, and must contrast that with the special education services the local school system provides. They must publish their tuition and fees, and must cap tuition at the amount charged to students without scholarships.

The major differences across program regulatory environments can be found in Table 1 below. As illustrated, the LSP has the most requirements for participating schools, and the Center for Education Reform (2014) gave the LSP the lowest grade for regulatory freedom.

Table 1: Regulatory Burdens for Each Program

\begin{tabular}{|c|c|c|c|}
\hline Variable & Indiana & DC & Louisiana \\
\hline Date Enacted & 2011 & 2004 & 2008 \\
\hline Average Funding Relative to Public School & $42 \%$ & $47 \%$ & $54 \%$ \\
\hline Eligibility Rate & $59 \%$ & $35 \%$ & $20 \%$ \\
\hline Private School Participation Rate & $70 \%$ & $78 \%$ & $33 \%$ \\
\hline Testing Requirement & $\mathrm{X}$ & $\mathrm{X}$ & $\mathrm{X}$ \\
\hline Open-Admissions Process & & & $\mathrm{X}$ \\
\hline Financial Reporting & $\mathrm{X}$ & $\mathrm{X}$ & $\mathrm{X}$ \\
\hline Parental Copay Prohibited & & & $\mathrm{X}$ \\
\hline Teacher Requirements & & $\mathrm{X}$ & \\
\hline Center for Education Reform Regulatory Score ${ }^{1}$ & A & B & $\mathrm{C}$ \\
\hline
\end{tabular}

\section{Data}

We use data from the nationally representative Private School Universe Survey from the school year 1999-00 to 2011-12. The target population for this survey is all private schools in the United States as defined by National Center for Education Statistics. Since the database contains unique school IDs for each period, we are able to follow individual schools over time. Since the

\footnotetext{
${ }^{1}$ https://www.edreform.com/wp-content/uploads/2014/08/VoucherRankings-Report5.pdf
} 
survey is completed every other school year, we use seven periods of data. For the LSP and the OSP, we use three periods before the voucher program enactment and two periods of data afterwards. For the IN CSP, however, we could only use one period of data after the intervention since the program was enacted and launched in 2011.

We are interested in five outcome variables located in the Private School Universe Survey questionnaire ${ }^{2}$ related to potential homogenization of individual schools. This information is located in questions $7 \mathrm{~b}, 8 \mathrm{a}, 12$, and $14 \mathrm{a}$. These questions ask whether the school is coeducational (Co-Ed), whether the school has a religious orientation or purpose, and the overall purpose or type of school. The different types of schools that we are interested include: regular, specialized (such as science/math, performing arts, gifted and talented, foreign language immersion), and alternative / non-traditional education. We are also interested in the percent of white students within a school to assess how program participation impacts study body composition.

Table 2: Timeline of Data Used

\begin{tabular}{l|rrrrrrr}
\hline Program & 2000 & 2002 & 2004 & 2006 & 2008 & 2010 & 2012 \\
\hline CSP (Indiana) & & & & & & Y & Y \\
\hline OSP (D.C.) & Y & Y & Y & Y & Y & & \\
\hline LSP (Louisiana) & & & Y & Y & Y & Y & Y \\
\hline
\end{tabular}

Note: "Y" indicates that a period is used. Thick black vertical lines indicate the period of voucher program enactment.

\section{Methods}

We use a school and year fixed effects regression approach of the form:

$$
\text { Outcome }_{\mathrm{it}}=\beta_{0}+\beta_{1} \text { Voucher }_{\mathrm{it}}+\alpha_{\mathrm{i}}+\varepsilon_{\mathrm{it}}
$$

Where Outcome is one of the six dependent variables of interest for school $i$ at time period $t$. Our six dependent variables of interest are the percent of white students and whether or not the

\footnotetext{
${ }^{2}$ https://nces.ed.gov/surveys/pss/pdf/Questionnaire_20112012.pdf
} 
school, $i$, identified itself as Co-Ed, Religious, Regular Ed, Specialized, or an Alternative / NonTraditional school in period $t$.

Voucher is the independent variable of interest, whether or not the institution was located in an educational market that had a voucher program in place, for school $i$ in period $t$. We expect that the coefficient of interest, $\beta_{1}$, will indicate more homogenization in the most-regulated program: the LSP. Since the other two programs have fewer regulations overall, we expect that the relationship will be less significant for the DC OSP and the IN CSP. Since these programs are targeted to low-income families, we expect that $\beta_{1}$ will indicate more racial diversity within schools.

Since many observable characteristics of schools can be argued as relatively constant over time, we present results for the year and school-level fixed-effects models without timevariant controls. In fact, including any controls at all would bias our estimates towards zero since we simply wish to observe the impact of the market environment on school-level characteristics. In other words, any characteristic of a school is an outcome of the school's competitive environment. Most importantly, our methods allow us to compare individual schools to themselves, over time, as they switch into voucher settings. As a robustness check, we use a random effects probit regression model as well. Since individual schools choose to identify as one of several different types of institutions, we also use a multinomial probit regression model as a robustness check. Since our sample sizes are all too small to rely on maximum likelihood estimation, our base school and year fixed effects regression model is preferred. 
Table 3: Descriptive Statistics by Program

\begin{tabular}{llllll}
\hline Variable & N & Mean & Std. Dev. & Min & Max \\
\hline CSP (Indiana) & & & & & \\
\hline Year & 1381 & 2011 & 1 & 2010 & 2012 \\
Enrollment & 1381 & 156 & 184.74 & 1 & 1452 \\
White (Percent) & 1381 & 83.86 & 23.62 & 0 & 100 \\
Co-Ed & 1381 & 0.99 & 0.08 & 0 & 1 \\
Religious & 1381 & 0.12 & 0.32 & 0 & 1 \\
Regular Ed & 1381 & 0.84 & 0.36 & 0 & 1 \\
Voucher Period & 1381 & 0.49 & 0.50 & 0 & 1 \\
Specialized & 1381 & 0.01 & 0.10 & 0 & 1 \\
Alternative / Other & 1381 & 0.02 & 0.14 & 0 & 1 \\
\hline OSP (D.C.) & & & & & \\
\hline Year & 430 & 2004 & 2.21 & 2000 & 2008 \\
Enrollment & 430 & 202 & 224.84 & 2 & 1097 \\
White (Percent) & 430 & 31.36 & 36.03 & 0 & 100 \\
Co-Ed & 430 & 0.93 & 0.26 & 0 & 1 \\
Religious & 430 & 0.50 & 0.50 & 0 & 1 \\
Regular Ed & 430 & 0.64 & 0.48 & 0 & 1 \\
Voucher Period & 430 & 0.39 & 0.49 & 0 & 1 \\
Specialized & 430 & 0.07 & 0.25 & 0 & 1 \\
Alternative / Other & 430 & 0.03 & 0.17 & 0 & 1 \\
\hline LSP (Louisiana) & & & & & \\
\hline Year & 1893 & 2008 & 2.85 & 2004 & 2012 \\
Enrollment & 1893 & 341 & 277.73 & 1 & 1745 \\
White (Percent) & 1893 & 72 & 31.66 & 0 & 100 \\
Co-Ed & 1893 & 0.94 & 0.25 & 0 & 1 \\
Religious & 1893 & 0.13 & 0.34 & 0 & 1 \\
Regular Ed & 1893 & 0.88 & 0.32 & 0 & 1 \\
Voucher Period & 1893 & 0.58 & 0.49 & 0 & 1 \\
Specialized & 1893 & 0.02 & 0.12 & 0 & 1 \\
Alternative / Other & 1893 & 0.02 & 0.14 & 0 & 1 \\
\hline & & & & &
\end{tabular}

\section{Results}

Private schools in Indiana did not change their overall school missions as a result of switching into a voucher program environment; however, individual private schools became slightly more-inclusive of minority students. Specifically, Indiana private schools were about a percentage point more inclusive of minority students after switching into a voucher environment. These results are as expected: the voucher program in Indiana has a moderate level of regulations 
for private schools, many of which, as mentioned before, were already adhered to by private schools for inclusion into the athletics association, and low-income students are those that are the least well served in their residentially-assigned schools.

\section{CSP}

Table 4: The Effect of the IN CSP on Homogenization

\begin{tabular}{|c|c|c|c|c|c|c|}
\hline & Co-Ed & Religious & Regular & Specialized & Alternative & White \\
\hline Voucher & $\begin{array}{c}\mathbf{0 . 0 0 0} \\
(\mathbf{1 . 0 0 0})\end{array}$ & $\begin{array}{l}-\mathbf{- 0 . 0 0 3} \\
(\mathbf{0 . 3 1 8})\end{array}$ & $\begin{array}{c}0.006 \\
(\mathbf{0 . 2 0 6})\end{array}$ & $\begin{array}{l}\mathbf{- 0 . 0 0 5} \\
(\mathbf{0 . 0 8 3})\end{array}$ & $\begin{array}{l}\mathbf{- 0 . 0 0 6} \\
(\mathbf{0 . 2 0 6})\end{array}$ & $\begin{array}{l}-1.125^{*} \\
(0.012)\end{array}$ \\
\hline $\begin{array}{l}\text { School/Year } \\
\text { Fixed Effects }\end{array}$ & Yes & Yes & Yes & Yes & Yes & Yes \\
\hline $\mathrm{R}^{2}$ Within & 0.0000 & 0.0016 & 0.0026 & 0.0048 & 0.0026 & 0.0100 \\
\hline Time Periods & 2 & 2 & 2 & 2 & 2 & 2 \\
\hline Schools & 755 & 755 & 755 & 755 & 755 & 755 \\
\hline $\mathrm{N}$ & 1381 & 1381 & 1381 & 1381 & 1381 & 1381 \\
\hline
\end{tabular}

Note: All models use school and year fixed effects regression from 2010 to 2012 . P-values in parentheses. $* \mathrm{p}<0.05, * * \mathrm{p}<0.01, * * * \mathrm{p}<0.001$

Private schools in D.C. have around a ten-percentage point lower likelihood of describing themselves as providing an alternative or non-traditional education after switching into the voucher environment. This is over half of a standard deviation decrease in the alternative classification in D.C. Importantly, the D.C. voucher program does not allow participating schools to have control their admissions processes. Schools that provide non-traditional or alternative educational services face substantial costs associated with accepting a diverse set of students, so they have an incentive to adapt their model to fit all types of students. It also appears that private schools switching in the D.C. voucher environment have around an eight-percentage point higher likelihood of describing themselves as a "regular" school; however, this result is only marginally significant at a p-value of 0.076 . The voucher program does not appear to affect 
the racial composition of private schools in D.C., perhaps because of a lack of student race variation in this particular sample.

\section{OSP}

Table 5: The Effect of the DC OSP on Homogenization

\begin{tabular}{lcccccc}
\hline & Co-Ed & Religious & Regular & Specialized & Alternative & White \\
\hline Voucher & $\begin{array}{c}\mathbf{0 . 0 0 0} \\
\mathbf{( 1 . 0 0 0 )}\end{array}$ & $\begin{array}{c}\mathbf{0 . 0 0 2} \\
\mathbf{( 0 . 8 7 9 )}\end{array}$ & $\begin{array}{c}\mathbf{0 . 0 8 3} \\
\mathbf{( 0 . 0 7 6 )}\end{array}$ & $\begin{array}{c}\mathbf{0 . 0 2 3} \\
\mathbf{( 0 . 5 3 0 )}\end{array}$ & $\begin{array}{c}\mathbf{- 0 . 0 9 8} \\
\mathbf{( 0 . 0 0 2})\end{array}$ & $\begin{array}{c}\mathbf{0 . 6 5 6} \\
(\mathbf{0 . 7 5 1})\end{array}$ \\
$\begin{array}{lccccc}\text { School/Year } \\
\text { Fixed Effects }\end{array}$ & Yes & Yes & Yes & Yes & Yes & Yes \\
& & & & & & \\
\hline $\mathrm{R}^{2}$ Within & 0.0000 & 0.0188 & 0.0161 & 0.0131 & 0.0492 & 0.0173 \\
\hline Time Periods & 5 & 5 & 5 & 5 & 5 & 5 \\
\hline Schools & 148 & 148 & 148 & 148 & 148 & 148 \\
\hline $\mathrm{N}$ & 430 & 430 & 430 & 430 & 430 & 430 \\
\hline
\end{tabular}

Note: All models use school and year fixed effects regression from 2000 to 2008 . P-values in parentheses. $* \mathrm{p}<0.05, * * \mathrm{p}<0.01, * * * \mathrm{p}<0.001$

The most interesting results emerge for the program that attaches the most regulations to voucher funding. As expected, the LSP appears to create homogenization within the private schooling sector for most of the measured outcomes. As a result of switching into the LSP environment, private schools in Louisiana have a 3.6-percentage point higher likelihood of describing themselves as regular, a 2.2-percentage point lower likelihood of describing themselves as specialized, and a 1.5-percentage point lower likelihood of describing themselves as non-traditional or alternative. These results range from around a tenth to a fifth of a standard deviation. In addition, the coefficients on Co-Ed and Religious are in their expected directions, indicating less specialization; however, these are not statistically significant, as their p-values are around 0.15 and 0.16 , respectively. Private schools in Louisiana experienced a 5.6-percentage point increase in minority students through switching into the voucher environment. This follows 
intuition, as the LSP is targeted to the least-advantaged students based on income and school quality.

LSP

Table 6: The Effect of the LSP on Homogenization

\begin{tabular}{lcccccc}
\hline & Co-Ed & Religious & Regular & Specialized & Alternative & White \\
\hline Voucher & $\mathbf{0 . 0 0 5}$ & $\mathbf{- 0 . 0 2 0}$ & $\mathbf{0 . 0 3 6 * *}$ & $\mathbf{- 0 . 0 2 2} *$ & $\mathbf{- 0 . 0 1 5 *}$ & $\mathbf{- 5 . 6 4 2 * * *}$ \\
& $\mathbf{( 0 . 1 4 9 )}$ & $\mathbf{( 0 . 1 6 0 )}$ & $\mathbf{( 0 . 0 0 1 )}$ & $\mathbf{( 0 . 0 1 2 )}$ & $\mathbf{( 0 . 0 4 9 )}$ & $\mathbf{( 0 . 0 0 0 )}$ \\
School/Year & Yes & Yes & Yes & Yes & Yes & Yes \\
Fixed Effects & & & & & & \\
\hline $\mathrm{R}^{2}$ Within & 0.0029 & 0.1553 & 0.0099 & 0.0071 & 0.0036 & 0.0447 \\
\hline Time Periods & 5 & 5 & 5 & 5 & 5 & 5 \\
\hline Schools & 532 & 532 & 532 & 532 & 532 & 532 \\
\hline $\mathrm{N}$ & 1893 & 1893 & 1893 & 1893 & 1893 & 1893 \\
\hline
\end{tabular}

Note: All models use school and year fixed effects regression from 2004 to 2012 . P-values in parentheses. $* \mathrm{p}<0.05, * * \mathrm{p}<0.01, * * * \mathrm{p}<0.001$. Results for regular and alternative are also robust to the random effects probit regression model and the multinomial probit regression model.

\section{Conclusion and Policy Implications}

Our results support our hypothesis that highly regulated voucher program environments induce homogenization in the supply of schools. We argue that the results are causal estimates of the impact of regulations on the homogenization of schools for a few reasons: (1) our econometric methodology allows us to control for all time-invariant characteristics of private schools, (2) our analysis compares three different regulatory environments, finding the strongest homogenizing effects for the LSP, fewer effects for the OSP, and no effects for the CSP, and (3) no other observable differences in the voucher programs would intuitively lead to different levels of specialization. 
Intuitively, homogenization in the supply of schools could at least partially have led to the negative experimental achievement results for the LSP. If student needs, learning abilities, desires, and interests are unique, specialized services should lead to improved outcomes. On the other hand, homogenization could lead to negative impacts for students, even if children are switching into an identical environment, since students must adapt to costs associated with moving schools.

Since private school choice programs are being proposed in several locations across the United States, decision-makers ought to pay close attention to policy design. While additional regulations often appear beneficial, especially since they give policy-makers the illusion of control, costs of program participation can lead to unintended consequences for children. Our estimates indicate that additional regulations could reduce specialization in the supply of schooling, and, as a result, fewer choices for families. If the diverse backgrounds, interests, and abilities of children are not matched with the available institutions, educational choice programs could fail to lead to improved outcomes. Consequently, decision-makers must balance the costs of regulation, such as homogenization in the supply of schools, with the benefits of regulation, such as perceived control, in order to design the educational choice policies that work best for families and society overall. 


\section{References}

Abdulkadiroglu, A., Pathak, P. A., \& Walters, C. R. (2015). School vouchers and student achievement: First-year evidence from the Louisiana Scholarship Program. Cambridge, MA: National Bureau of Economic Research.

Astley, G. W., \& Van de Ven, A. H. (1983). Central perspectives and debates in organization theory. Administrative Sciences Quarterly, 28(2), 245 - 273.

Barnard, J., Frangakis, C. E., Hill, J. L., \& Rubin, D. B. (2003). Principal stratification approach to broken randomized experiments: A case study of school choice vouchers in New York City. Journal of the American Statistical Association, 98(462), 299-323.

Bator, F. M. (1958). The anatomy of market failure. The Quarterly Journal of Economics, 72(3), 351-379.

Berends, M., Goldring, E., Stein, M., \& Cravens, X. (2010). Instructional conditions in charter schools and students' mathematics achievement gains. American Journal of Education, $116(3), 303-335$.

Bettinger, E., \& Slonim, R. (2006). Using experimental economics to measure the effects of a natural educational experiment on altruism. Journal of Public Economics, 90(8), $1625-$ 1648.

Bitler, M., Domina, T., Penner, E., \& Hoynes, H. (2015). Distributional analysis in educational evaluation: A case study from the New York City voucher program. Journal of Research on Educational Effectiveness, 8(3), 419-450.

Bulletin 133. (2104). Part CLIII. Bulletin 133-Scholarship Programs. Louisiana Department of Education. 
Carnoy, M., Adamson, F., Chudgar, A., Luschei, T. F., \& Witte, J. F. (2007). Vouchers and public school performance: A case study of the Milwaukee Parental Choice Program. Washington, DC: Economic Policy Institute.

Cavazos, S. (2016). Six things to know about Indiana's school voucher program, a model Betsy DeVos could support. Chalkbeat. Retrieved from: http://www.chalkbeat.org/posts/in/2016/11/30/six-things-to-know-about-indianas-schoolvoucher-program-a-possible-model-for-betsy-devos/

Center for Education Reform (2014). School choice today: Voucher laws across the states. Retrieved from: https://www.edreform.com/2014/08/school-choice-today-voucher-lawsacross-the-states-1/

Chingos, M. \& Peterson, P. (2013). Experimentally estimated impacts of a school choice intervention on long-term educational outcomes: The effects of school vouchers on college enrollment. Retrieved from: https://www.hks.harvard.edu/pepg/PDF/Papers/PEPG12-10.pdf

Chingos, M. M., \& Peterson, P. E. (2015). Experimentally estimated impacts of school vouchers on college enrollment and degree attainment. Journal of Public Economics, 122, 1-12.

Costrell, R. M. (2010). The fiscal impact of the Milwaukee Parental Choice Program: 2010-2011 update and policy options. School Choice Demonstration Project Milwaukee Evaluation Report \#22.

Dacin, M. T. (1997). Isomorphism in context: The power and prescription of institutional norms. The Academy of Management Journal, 40(1), 46 - 81.

DeAngelis \& Wolf (2016). The school choice voucher: A "get out of jail" card? EDRE Working Paper 2016-03. Available at SSRN: https://ssrn.com/abstract=2743541 
DiMaggio, P. J., \& Powell, W. W. (1983). The iron cage revisited: Institutional isomorphism and collective rationality in organizational fields. American Sociological Review, 48(2), 147 160.

Dynarski, M., Rui, N., Webber, A., \& Gutmann, B. (2017). Evaluation of the DC Opportunity Scholarship Program: Impacts after one year. NCEE 2017-4022. National Center for Education Evaluation and Regional Assistance.

EdChoice, (2017). School choice in America Dashboard. Retrieved from: https://www.edchoice.org/school-choice/school-choice-in-america/

Egalite, A. J. (2013). Measuring competitive effects from school voucher programs: A systematic review. Journal of School Choice, 7(4), 443-464.

Egalite, A. J., Mills, J. N., \& Wolf, P. J. (2017). The impact of targeted school vouchers on racial stratification in Louisiana schools. Education and Urban Society, 49(3), 271-296.

Fleming, D. J., Mitchell, W., \& McNally, M. (2014). Can markets make citizens? School vouchers, political tolerance, and civic engagement. Journal of School Choice, 8(2), 213236.

Forster, G. (2016). A win-win solution. The empirical evidence on school choice. The Friedman Foundation for Educational Choice.

Greene, J. P., Peterson, P. E., \& Du, J. (1999). Effectiveness of school choice: The Milwaukee experiment. Education and Urban Society, 31(2), 190-213.

Greene, J. P. (2000). The effect of school choice: An evaluation of the charlotte children's scholarship fund program. Civic Report, 12, 1-15. 
Greene, J. P., Mills, J. N., \& Buck, S. (2010). The Milwaukee Parental Choice Program's effect on school integration. School Choice Demonstration Project Milwaukee Evaluation Report \#20.

Greene, J. P., \& Winters, M. A. (2006). An evaluation of the effect of DC's voucher program on public school achievement and racial integration after one year. Education Working Paper No. 10. Center for Civic Innovation.

Hawley, A. (1968). Human Ecology, 328-37 in David L. Sills (ed.), International Encyclopedia of the Social Sciences. New York: Macmillan.

Howell, W. \& Peterson, P. (2006). The education gap: Vouchers and urban schools. ( ${ }^{\text {nd }}$ Ed.). Washington, D.C.: Brookings Institution.

Howell, W. G., Wolf, P. J., Campbell, D. E., \& Peterson, P. E. (2002). School vouchers and academic performance: Results from three randomized field trials. Journal of Policy Analysis and Management, 21(2), 191-217.

Hoxby, C. (2001). Rising tide. Education Next, 1(4), 68 - 75.

Jin, H., Barnard, J., \& Rubin, D. B. (2010). A modified general location model for noncompliance with missing data: Revisiting the New York City School Choice Scholarship Program using principal stratification. Journal of Educational and Behavioral Statistics, 35(2), 154-173.

Krueger, A. B., \& Zhu, P. (2004). Another look at the New York City school voucher experiment. American Behavioral Scientist, 47(5), 658-698.

Lubienski, C. (2003). Innovation in education markets: Theory and evidence on the impact of competition and choice in charter schools. American Educational Research Journal, 40(2), $395-443$. 
Meyer, J. W., \& Rowan, B. (1978). The structure of educational organizations. In M. W. Meyer, et al. (Eds.), Environments and Organizations. San Francisco, CA. Sage Publications, Inc.

Meyer, J. W., Scott, W. R., \& Deal, T. E. (1992). Institutional and technical sources of organizational structure: Explaining the structure of educational organization. In J. W. Meyer \& W. R. Scott (Eds.), Organizational Environments: Ritual and Rationality (pp. 45 - 70). Newbury Park, CA: Sage Publications, Inc.

Mills, J. N., Cheng, A., Hitt, C. E., Wolf, P. J., \& Greene, J. P. (2016). Measures of student noncognitive skills and political tolerance after two years of the Louisiana Scholarship Program. Louisiana Scholarship Program Evaluation Report \#2. School Choice Demonstration Project.

Mills, J. N., \& Wolf, P. J. (2017). The effects of the Louisiana Scholarship Program on student achievement after three years. Louisiana Scholarship Program Evaluation Report \#7. School Choice Demonstration Project, University of Arkansas.

National Center for Education Statistics (2017). Private School Universe Survey (PSS). Data and documentation. Retrieved from: https://nces.ed.gov/surveys/pss/pssdata.asp

Oplatka, I. (2004). The characteristics of school organization and the constraints on market ideology in education: an institutional view. Journal of Education Policy, 19(2), 143 161.

Pigou, A. C. (2013). The economics of welfare. Palgrave Macmillan.

Scafidi, B. (2012). The fiscal effects of school choice programs on public school districts. National Research. Friedman Foundation for Educational Choice. 
Scott, W. R. (1987). Organizations: Rational, natural, and open systems. Englewood Cliffs, NJ: Prentice Hall.

Shakeel, D, M., Anderson, K. P., \& Wolf, P. J. (2016). The participant effects of private school vouchers throughout the globe: A meta-analytic and systematic review. University of Arkansas Department of Education Reform Working Paper.

Sude, Y., DeAngelis, C. A., \& Wolf, P. J. (2017). Supplying choice: An analysis of school participation decisions in voucher programs in Washington, DC, Indiana, and Louisiana. Journal of School Choice, 10(3), 1-26.

Tullock, G., Brady, G. L., \& Seldon, A. (2002). Government failure: a primer in public choice. Cato Institute.

Westwood, R. and Clegg, S. (2003). Debating organization: Point-counterpoint in organization studies. Malden, MA: Blackwell Publishing.

Wolf, P. J., Kisida, B., Gutmann, B., Puma, M., Eissa, N., \& Rizzo, L. (2013). School vouchers and student outcomes: Experimental evidence from Washington, DC. Journal of Policy Analysis and Management, 32(2), 246-270. 